\title{
IMPACT OF ENTREPRENEURSHIP EDUCATION ON BEHAVIOR OF UNIVERSITY STUDENTS WITH MEDIATING EFFECT OF INTENTIONS
}

\author{
Maheen, Khair Un Nisa, and Muhammad Faisal Sultan
}

\begin{abstract}
This study is based on applied research and intends to find out the impact of entrepreneurial education on the behavior of university students with the mediation of intentions of students toward entrepreneurship. Although there are several studies associated with the topic, but the paper is unique because the data is based upon a specific geographical location, Karachi which is a metropolitan city of Pakistan. There is a severe dearth of entrepreneurial mindset in Pakistan and investigative studies related to the region in previous literature. The data for this study has been collected through a close ended questionnaire. The study is pervasive in nature as the study is potent in increase of knowledge in the area of business as well as universities. Although the study is supplemented with some limitations as the data collected from developing country like Pakistan is not coherent with the other economies. Although the value of paper is not over shadowed, and this can be used for applicative reasoning for universities and other academies. The sample size for the study is of 150 to 200 software has been used for the purpose of data analysis. Although the paper is supported by descriptive as well as inferential analysis in order to make findings of the study potent and reliable enough. The use of the software is indicated that there is a relationship between entrepreneurial education and behavior of university students toward entrepreneurship.
\end{abstract}

Keywords: Entrepreneurial Education, Behavior, Business-Students Intentions.

\section{INTRODUCTION}

Entrepreneurship provides the platform for new innovation and creativity and direction to the business world. It rises competition to the business market. Entrepreneurship plays important 
role by increases the jobs in the market and creation of employment in the growth of the country (Farrukh, Chong, Mansori, \& Ravan, 2017). (Farrukh, Wei, \& Abdulla, organizational commitment, 2016) Countries like USA, Germany and Japan become developed by their large numbers of entrepreneurs who rises their economic growth. (Prakash, Jain, \& Chauhan, 2015) The main objective of entrepreneurship is making profit. (Abu Haris \& Rahman, 2017) Eventually recognizing the opportunities re the key elements of entrepreneurship with the intention of utilizing such opportunities. Entrepreneurial intention is beneficial for realize the process of entrepreneurship towards entrepreneurial behavior of students. The attention towards entrepreneurship education has increased because for business students it is very important to teach them entrepreneurship education (Debarliev, Janeshka-lliev, Bozhinovska, \& Ilieva, 2015). (Ajzen, 1991) Studies that entrepreneurial intentions of students increase from entrepreneurship education. (Vesalainan \& Pihkala, 1999) University administrators around the world are deliberately discussed about the entrepreneurship education at university level. (Drennan \& Renfrow, 2005) Recent studies identifying the significance of behavioral aspects of entrepreneurship education. (Krueger Jr, Reilly, \& Carsrud, 2000) The entrepreneurial behavior is shaped by the intentions. (Izquierdo \& Buelens, 2008) Entrepreneurship education is the key element of increase entrepreneurial behavior of potential entrepreneurs with the help of intentions. (Lee \& Wong, 2004) Entrepreneurial intentions are directly indicate towards entrepreneurial behavior. (Linan, 2004) Intentions as a whole can be defined as the mindset of a person towards its goals. (Linan \& Chang, Testing the entrepreneurial intention model on two country sample, 2006) The intentions towards making a business enterprise is taken through individual entrepreneurial intention. (Noel, 1998) The advanced learning of entrepreneurship is disclosed by the entrepreneurial intention. (Ajzen, Perceived behavioral control, self eficacy and the theory of planned behavior, 2002)Gaining knowledge about entrepreneurial intentions help to understand about entrepreneurial behavior.

\section{PROBLEM STATEMENT}

Solomon, Duffy, and Tarabishy (2002), stated that this study contribute in term of theory, methodology and practice.it uses the framework of behavior of students to make the useful knowledge about entrepreneurship education and entrepreneurial behavior. Furthermore (Kakkonen, 2010) suggested that behavior is an essential element which help educator to evaluate their programs. (Temoor, Sara, \& Farukh, 2018) Suggested that entrepreneurship education plays a vital role in influencing students towards entrepreneurial intentions through 
various programs is very beneficial for student's future development. But this study have some limitations like small sample size which restrict from the reliability of the results. Furthermore the data collection of this study is limited to only one university of Pakistan in the capital city which is a private university. More researches are required from the other cities of the country and universities from private and government sector equally to evaluate that findings from this research is equally implemented to the other areas of Pakistan.

\section{THEORETICAL FRAMEWORK}

Entrepreneurial intention is an element that directly indicate towards entrepreneurial behavior (Soloman \& Fernald, 2005). The attitude of a person towards that behavior can be perceived by the intention of a person towards behavior. (Zeithaml \& Rice, 2016) Entrepreneurship education important because it bring the positive impact on entrepreneurial intention of students by giving them entrepreneurship education. (Katz, 2003) Suggested that the aim of entrepreneurship education should be to increase the student's intention to become entrepreneur. He merge two theories theory of planned behavior and theory of entrepreneurial event to make the model. (Ajzen, 2001) The TPB identify the individual's intentions to making the relation between intention and behavior. (Autio \& R.H, 2005) Especially where there are many difficulties to predict the individual intentions towards behavior this model helps.

\section{RESEARCH MODEL}

ENTREPRENEURSHIP EDUCATION
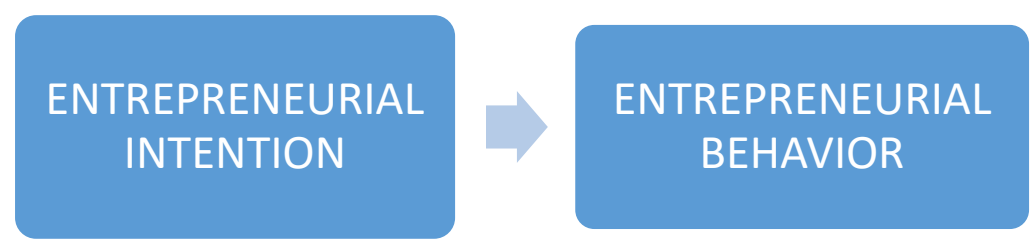

\section{RESEARCH OBJECTIVES}

- $\quad$ To see the impact of entrepreneurship education on entrepreneurial behavior.

- To verify the mediation of entrepreneurial intention in the relationship between entrepreneurship education and entrepreneurial behavior.

\section{RESEARCH HYPOTHESIS}


HO: There is no relationship between entrepreneurship education and entrepreneurial behavior.

H1: There is a relationship between entrepreneurship education and entrepreneurial behavior.

HO: Entrepreneurial behavior does not mediate the relationship of entrepreneurship education and entrepreneurial behavior.

H1: Entrepreneurial behavior not mediate the relationship of entrepreneurship education and entrepreneurial behavior.

\section{LIMITATIONS}

In this study students were asked to evaluate themselves. About their intentions and their entrepreneurial programs their university offering them. Their answers might be prejudiced by their situations. In further studies it would differentiate the courses related to entrepreneurship education to check whether students with their entrepreneurial intention differ from students without those intentions. Also, the teaching methods is different and student's perception about it is different. Moreover, the duration of courses related to entrepreneurship education have different impact on intentions toward entrepreneurship.

\section{SCOPE OF RESEARCH}

This study makes important practical contribution in the entrepreneurial intention of the students in Pakistan with the development of entrepreneurship education for better portray of how entrepreneurship intention established and how possible entrepreneur perceived it to commence their business. This study helps to find out the entrepreneurship education influence the entrepreneurial intention of student and have positive impact on entrepreneurial behavior of potential students who are willingly wanting to be an entrepreneur (Temoor, Sara, \& Farukh, 2018).

\section{SIGNIFICANCE OF THE RESEARCH}

This study influence universities to take in consideration about various contribution to achieving the objectives to motivate fresh graduates and young ones for new business startups. (Linan, Rodriguez-Cohard, \& Rueda-Cantuche, Factors effecting entrepreneurial intention levels; a role for education, 2010) Suggested that in the developing world make entrepreneurs and give them sustainable environment is essential to the growth of entrepreneurship. 
Furthermore this study helps to develop entrepreneurship education in the future. It also help universities to make programs and established platform for startup of new businesses. (Temoor, Sara, \& Farukh, 2018) Suggested that by making of operative programs with practical implementation which increase the entrepreneurial intention of students. This research is in interest of teachers and the sponsor of entrepreneurship. Because it explain the concept of entrepreneurship education the entrepreneurial intention for inventing and founding and the entrepreneurial behavior towards executing of the idea of entrepreneurship.

\section{LITERATURE REVIEW}

\section{Entrepreneurship Education}

Studies claim that entrepreneurship education in universities covers the whole opportunity of business (Dyer, 1994). Many researchers have been studied about entrepreneurship education at university level. (Robinson \& M, 2004) Claim that there is a positive correlation between entrepreneurship education and business creators. In universities and out of universities the concentration towards entrepreneurship education and the progress in entrepreneurs increasing day by day. (Krueger, Reilly, \& Carsrud, 2000) Argued that all potential students and ventures should be encouraged to getting entrepreneurship education. (Adenipekun , 2004) Evaluate that students who are graduate from entrepreneurship are three times more expected to start their own business and self-employed. (Thandi \& Sharma, 2003) Entrepreneurship education supports universities to establish enterprise culture among students who are future entrepreneur. Universities through-out the world have progressively identifies that for the increasingly changing market trends entrepreneurship education is very important for those who wants to start their own business. (Uwameiye \& Uwameiye, 2006) Entrepreneurship education is related to the management education concept in universities. Entrepreneurship education helps to identifying opportunities which consider as the skills that can be improve through the entrepreneurship education.

\section{Entrepreneurship Education and Entrepreneurial Intention}

Initiation of building relationship between students intention and entrepreneurship education to start new business is a dire need today (Krueger \& Brazeal, 1994). Entrepreneurship education helps students to build confidence that they need to establish an enterprise. (Zhao, Hill, \& Seiberts, 2005) Explain that getting entrepreneurship education has positive impact on entrepreneurial intentions and student's future selections and their effects are beneficial. 
(Davidsson, 1995) Studies found that entrepreneurship education increase the apparent possibility for new ventures by increasing awareness and building confidence. It also encouraged or motivate students by showing them that entrepreneurship education is extremely required in the society and most beneficial. (Mcstay, 2008) Give evidence that entrepreneurship education concept is based on the perception that entrepreneurial intentions can increase and learned by them. The findings of (Izedonmi \& Okafor, 2010) shows that entrepreneurship education has expressively influenced the student's intentions to become entrepreneur. (Douglas \& Shepherd, 2002) Stated that there is positive relationship between entrepreneurship education and entrepreneurial intention of students to become an entrepreneur.

\section{Entrepreneurial Intention and Entrepreneurial Behavior}

People work for getting benefits at the end of the day but the intention of getting profit is keep in his mind at start of the day (Gorman, Hanlon, \& King, 1997; Detienne \& Chandler, 2004). Similarly if students have expect that entrepreneurship is beneficial for them and it supports them to fulfil their dreams and achieving their goals and objectives they will create positive intention towards entrepreneurship. Therefore, intentions towards entrepreneurship helps to evaluate that to what extent students have required the assessment of entrepreneurial behavior. (Gibb, 2002) Entrepreneurial intention is referring to what extent the students will perform entrepreneurial behavior. (Peterman \& Kennedy, 2003) It is observed by the preference of the individual toward entrepreneurial behavior in the future. (Weaver, Dickson, \& Soloman, 2006) The intentions towards start a new business is termed as entrepreneurial intention. (Pittaway \& Cope, 2007) Stated that by creating new products, market and process individual creates creative start-ups which make them entrepreneur. (Fritsch, 2011) Such intentions is directly proceed towards entrepreneurial behavior. If the entrepreneurial intention is greater the entrepreneurial behavior is also greater. (Buba, Ayuba, \& Aminu, 2015) Argued that entrepreneurial intention reflects the student's enthusiasms towards entrepreneurial behavior.

\section{RESEARCH METHODOLOGY}

The philosophy of this research is ontology which is explained by the (Morgan \& Burrell, 1979) ontology describes the reality and its presence. (Holden \& Lynch, 2004) Claims that ontology mainly focuses on two aspects in which the first one is objectivism and the other one is subjectivism. The objectivism views the reality which exists out there in an external 
environment most likely to tangible. On the other hand, subjectivism refers to the reality created by the person and the perception of his mind (Morgan \& Smircich, 1980).

\section{RESEARCH METHODOLOGY}

The method of this research is deductive according to (Trochim \& Donnelly, 2008) where the researcher was finding out the relationship and the impact of anything on different aspects. Similarly, the researcher was evaluating the impact of external outsourcing of recruitment on time saving and cost reduction.

\section{PURPOSE OF STUDY}

The purpose of the study is descriptive which is suggested by the (Zikmond, Babin, Carr, \& Griffin, 2010) when the researcher tries to gather the information and some conditions regarding with specific questions and find the causal impact on the research. The descriptive study of this research indicates that the multiple resources are compiled in a single platform which generates some questions and the knowledgeable results come out after the results.

\section{RESEARCH APPROACH}

The approach of the study is quantitative in nature (Amaratunga, Baldry, Sarshar, \& Newton, 2002) where the data will be collected through questionnaire including some questions e.g., structured question asking to employees. (Saunders, Lewis, \& Thornhill, 2006).

Sampling method adopted in this study is the simple random sampling of employees work in a banking sector in Karachi, Pakistan.

\section{Nature of Respondents}

The data was collected from each individual working in a private banking sector of Karachi. Data was analyzed through the Likert scale which shows to select any option like, Strongly Disagree, Disagree, Neutral, Agree, Strongly Agree. After the collection of respondent's data, the researcher was picked a statistical tool e.g. Smart Pls. The research was doing to find out the correlation of external outsourcing of recruitment between cost reduction and time saving.

\section{Population}

Population in a research is a group of people who have same characteristics and belongs to same class to get the relevant answers with those people and use to compile in a research. For 
every research it is an important element to deeply understand its population who take part to fulfill the research data and getting out the results. With the help of population researcher not only obtain the data but to find the exact values of their results and their favorable outcomes.

\section{Sampling Technique}

The sampling technique was a probability sampling in which the researcher has a known population for his research. (Zikmond, Babin, Carr, \& Griffin, 2010). This process of sampling includes four different types which include the sample methods, technique, size of sample and known population (Saunders, Lewis, \& Thornhill, 2006).

\section{Methods of Sampling}

The method of sampling is a simple random sampling in which the researcher did convenience sampling. It means conduct the data in banking sector and fills the questionnaire through these all employees who work in this sector.

\section{Sample Size}

The sample size was 225 after the removal of unengaged responses, it was 200 which implemented for testing and data put in a SPSS and smart Pls for getting the results.

\section{RESULTS AND DISCUSSION}

\section{Frequency Table}

Table 1. Gender

\begin{tabular}{|c|c|c|c|c|c|}
\hline & & Frequency & Percent & Valid Percent & $\begin{array}{l}\text { Cumulative } \\
\text { Percent }\end{array}$ \\
\hline \multirow[t]{3}{*}{ Valid } & MALE & 143 & 71.4 & 71.4 & 71.4 \\
\hline & FEMALE & 57 & 28.6 & 28.6 & 100.0 \\
\hline & Total & 200 & 100.0 & 100.0 & \\
\hline
\end{tabular}

In frequency of gender there are $71.4 \%$ male respondents and $28.6 \%$ female respondents.

\section{Table 2 Age}




\begin{tabular}{|ll|l|l|l|l|}
\hline & & Frequency & Percent & Valid Percent & \multicolumn{1}{c|}{$\begin{array}{c}\text { Cumulative } \\
\text { Percent }\end{array}$} \\
\hline Valid & 21 TO 30 & 75 & 37.3 & 37.3 & 37.3 \\
& 31 TO 40 & 98 & 49.2 & 49.2 & 86.5 \\
41 TO 50 & 24 & 11.9 & 11.9 & 98.4 \\
51 AND ABOVE & 3 & 1.6 & 1.6 & 100.0 \\
Total & 200 & 100.0 & 100.0 & \\
\hline
\end{tabular}

The age frequency shows that respondent of age 21 to 30 are $37.3 \%$ respondent of age 31 to 40 are $49.2 \%$ respondents of age 41 to 50 are $11.9 \%$ and respondent of age 51 and above are $1.6 \%$.

Table 3. Qualifications

\begin{tabular}{|ll|l|l|l|l|}
\hline & & Frequency & Percent & Valid Percent & $\begin{array}{l}\text { Cumulative } \\
\text { Percent }\end{array}$ \\
\hline Valid & METRIC & 1 & .5 & .5 & .5 \\
& INTERMEDIATE & 16 & 8.1 & 8.1 & 8.6 \\
BACHELORS & 114 & 57.3 & 57.3 & 65.9 \\
MASTERS & 63 & 31.9 & 31.9 & 97.8 \\
OTHERS & 6 & 2.2 & 2.2 & 100.0 \\
Total & 200 & & 100.0 & 100.0 & \\
\hline
\end{tabular}

The above table shows that respondent qualification of metric are $0.5 \%$ intermediate are $8.1 \%$ bachelors are $57.3 \%$ masters are $31.9 \%$ and others are $2.2 \%$

Table 4 Work Experience

\begin{tabular}{|ll|l|l|l|l|}
\hline & & & & Cumulative \\
\hline Valid & LESS THAN 1 YEAR & 31 & 15.7 & 15.7 & 15.7 \\
& 1-3 YEARS & 74 & 36.8 & 36.8 & 52.4 \\
4-6 YEARS & 44 & 22.2 & 22.2 & 74.6 \\
7-5 YEARS & 21 & 10.3 & 10.3 & 84.9 \\
10 YEARS AND & 30 & 15.1 & 15.1 & 100.0 \\
ABOVE & 200 & 100.0 & 100.0 & \\
Total & &
\end{tabular}


The above table shows the number of years of qualification of respondents. Respondents experience less than 1 year are $15.7 \%, 1-3$ years are $36.8 \%$, 4-6 years are $22.2 \%, 7-5$ years are $10.3 \%$ and 10 years and above are $15.1 \%$

Table 5 Construct Reliability and Validity Analysis

\begin{tabular}{|l|l|l|c|c|}
\hline & $\begin{array}{l}\text { Cronbach's } \\
\text { Alpha }\end{array}$ & rho_A & $\begin{array}{l}\text { Composite } \\
\text { Reliability }\end{array}$ & $\begin{array}{l}\text { Average Variance } \\
\text { Extracted (AVE) }\end{array}$ \\
\hline Entrepreneurial Behavior & 0.872 & 0.885 & 0.906 & 0.66 \\
\hline $\begin{array}{l}\text { Entrepreneurship } \\
\text { Education }\end{array}$ & 0.916 & 0.916 & 0.937 & 0.748 \\
\hline Entrepreneurial Intention & 0.802 & 0.906 & 0.928 & 0.72 \\
\hline
\end{tabular}

In table 5 the values included are Cronbach's alpha, rho_A, composite reliability and average variance extracted the Cronbach's alpha values are acceptable if it is greater than 0.7 as this value has been stated by the author (Mohsen, Tavakol, \& Dennick, 2011). On the other hand, accurate (Taber, 2017) . indicated that acceptable value of alpha is greater than 0.60 , the abovementioned table explore the value of entrepreneurial behavior is 0.872 ,entrepreneurship education is 0.916 and entrepreneurial intention is 0.802 which shows that all the values are greater than 0.7 good reliability and consistency of the respondent selection of question responses. On the other hand, if Rho_A values should be greater than 0.7 as author (Taber, 2017). Concluded, the values of Rho_A of entrepreneurial behavior is 0.885 , entrepreneurship education is 0.916 and entrepreneurial intention is 0.906 which show that all the values are acceptable. The average variance Extracted value indicated by author (Forner, \& Perker, 1981) should be greater than 0.50 and the values in table 1 represent entrepreneurial behavior is 0.66 , entrepreneurship education is 0.748 and entrepreneurial intention is 0.72 these values are above than 0.50 which shows that all the values are acceptable. The Cronbach's alpha, rho_A, composite reliability also proved that the accuracy of data. The reliability of responses is accurate because the values of Cronbach's alpha, rho_A, composite reliability values are greater than to 0.7 .

Table 6 Discriminant Validity

\begin{tabular}{|l|l|l|l|}
\hline Cross Loading & \multicolumn{3}{l|}{} \\
\hline & $\begin{array}{l}\text { Entrepreneurial } \\
\text { Behavior }\end{array}$ & $\begin{array}{l}\text { Entrepreneurship } \\
\text { Education }\end{array}$ & $\begin{array}{l}\text { Entrepreneurial } \\
\text { Intension }\end{array}$ \\
\hline B1 & 0.827 & 0.824 & 0.697 \\
\hline B2 & 0.86 & 0.864 & 0.738 \\
\hline B3 & 0.801 & 0.615 & 0.59 \\
\hline
\end{tabular}




\begin{tabular}{|l|l|l|l|} 
B4 & 0.765 & 0.598 & 0.636 \\
\hline B5 & 0.806 & 0.646 & 0.677 \\
\hline EE1 & 0.785 & 0.882 & 0.722 \\
\hline EE2 & 0.81 & 0.898 & 0.725 \\
\hline EE3 & 0.792 & 0.875 & 0.735 \\
\hline EE4 & 0.694 & 0.816 & 0.823 \\
\hline EE5 & 0.762 & 0.851 & 0.858 \\
\hline EI1 & 0.705 & 0.808 & 0.86 \\
\hline EI2 & 0.716 & 0.782 & 0.876 \\
\hline EI3 & 0.752 & 0.818 & 0.902 \\
\hline EI4 & 0.669 & 0.704 & 0.818 \\
\hline EI5 & 0.657 & 0.674 & 0.78 \\
\hline
\end{tabular}

Table 7 Fornell Larcker

\begin{tabular}{|l|l|l|l|l|}
\hline & $\begin{array}{l}\text { Entrepreneurial } \\
\text { Behavior }\end{array}$ & $\begin{array}{l}\text { Entrepreneurship } \\
\text { Education }\end{array}$ & $\begin{array}{l}\text { Entrepreneurial } \\
\text { Intention }\end{array}$ \\
\hline Entrepreneurial Behavior & 0.412 & & & \\
\hline Entrepreneurship Education & 0.489 & 0.565 & & \\
\hline Entrepreneurial Intention & 0.426 & 0.595 & 0.598 & \\
\hline
\end{tabular}

Table 8 HTMT

\begin{tabular}{|l|l|l|l|}
\hline & $\begin{array}{l}\text { Entrepreneurial } \\
\text { Behavior }\end{array}$ & $\begin{array}{l}\text { Entrepreneurship } \\
\text { Education }\end{array}$ & $\begin{array}{l}\text { Entrepreneurial } \\
\text { Intention }\end{array}$ \\
\hline Entrepreneurial Behavior & & \\
\hline Entrepreneurship Education & 0.475 & & \\
\hline Entrepreneurial Intention & 0.424 & 0.682 & \\
\hline
\end{tabular}

Cross loading is checking the indicator scaling and check the validity of questions. Cross loading must be decrease in orthogonal check the value of cross loading is 0.20 acceptable and the value must be less than 0.20 in another row and column of indicators (Ringle, Silva, \& Bido, 2014). Another author also predicts the value of cross loading that less than 0.2 in the orthogonal directions every value or other indicators is least to 0.2 (Abdul Munir, 2018)'as it has been indicated in cross loading table that in table cross loading the values start from B 1 
to $\mathrm{B} 5$ the values are loaded highest in the given column, the values starting from EE 1 to EE 6 in its specified row, the values of EI in its column the values are highly loaded in the column which means values are highly loaded. the cross loading values match the criteria of the standard values and every indicator show discriminate with each other orthogonal values of every indicator are less than or equal to 0.2 and the high value of indicator to show the discrimination of every indicator responses. Author suggested that the model to check the discriminate validity of the data the values of square root of AVE is greater than the coefficient and the diagonal values should be greater than off diagonal values (Fornell \& Larcker, 1981). According to the Fornell Larcker proved that every variable of model does not match each other. Every AVE value is maximum another one and create a correlation of variables of latent squared with off diagonal. as in the table 2 the diagonal values indicated that the vales entrepreneurial behavior is 0.412 which is greater than off diagonal value, the value of entrepreneurship education is 0.565 which is greater than off diagonal value, entrepreneurial intention is 0.598 which means that the values of discriminate validity is perfect . The result matches the criteria of the model and shows the discriminate of the variables validity. (Ringle et ,al 2014) also explain the HTMT values less than to 0.8 to 0.85 these value show the relation variables to varibes is discriminate every variable do not match another one and show their validity as in table 3 showsw that the value of HTMT is less then 0.8 to 0.85 as per the author.

Table 9 R Square

\begin{tabular}{|l|l|l|}
\hline & $\begin{array}{l}\text { R } \\
\text { Square }\end{array}$ & $\begin{array}{l}\text { R Square } \\
\text { Adjusted }\end{array}$ \\
\hline Entrepreneurial Behavior & 0.784 & 0.783 \\
\hline Entrepreneurial Intention & 0.80 & 0.801 \\
\hline
\end{tabular}

Authors have suggested that the values of R Square is $2 \%$ greater than or less than $2 \%$ variance the effect is poor, and the $13 \%$ value of $\mathrm{R}$ square is better, and the $26 \%$ values are good variances the value of the variances impact on IVs (Cohen, 1988). Value is greater than 0.27 in fact more than 0.5 therefore model said to be fit for both variable.

\section{RESEARCH MODEL}




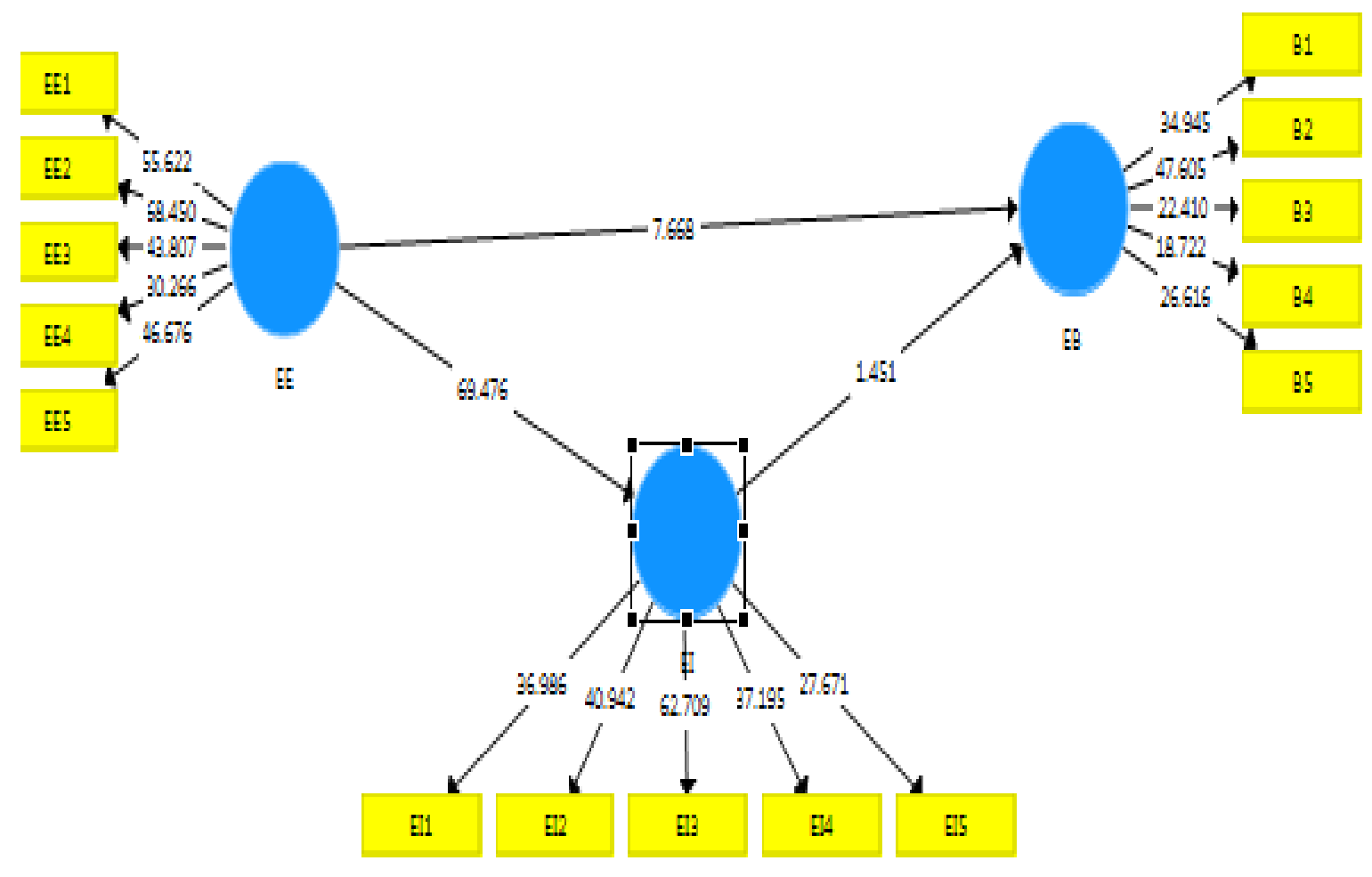

Table 10 Bootstrapping

\begin{tabular}{|c|c|c|c|c|c|}
\hline \multicolumn{6}{|l|}{ Path Coefficients } \\
\hline & $\begin{array}{l}\text { Original } \\
\text { Sample } \\
\text { (O) }\end{array}$ & $\begin{array}{l}\text { Sample } \\
\text { Mean (M) }\end{array}$ & $\begin{array}{l}\text { Standard } \\
\text { Deviation } \\
\text { (STDEV) }\end{array}$ & $\begin{array}{l}\text { T Statistics } \\
(|\mathrm{O} / \mathrm{STDEV}|)\end{array}$ & $\begin{array}{l}\mathrm{P} \\
\text { Values }\end{array}$ \\
\hline $\begin{array}{l}\text { Entrepreneurship Education } \\
\text {-> Entrepreneurial } \\
\text { Behavior }\end{array}$ & 0.753 & 0.755 & 0.098 & 7.668 & 0.002 \\
\hline $\begin{array}{l}\text { Entrepreneurship Education } \\
\text {-> Entrepreneurial } \\
\text { Intention }\end{array}$ & 0.895 & 0.896 & 0.013 & 9.476 & 0.003 \\
\hline $\begin{array}{l}\text { Entrepreneurial Intention - } \\
>\text { Entrepreneurial Behavior }\end{array}$ & 0.152 & 0.151 & 0.105 & 3.451 & 0.048 \\
\hline
\end{tabular}

The table above give the significant values of $\mathrm{T}$ statistic and $\mathrm{P}$ values to show the impact of IVS to DV the acceptable value of $\mathrm{T}$ is $+/-2$ greater than and the $\mathrm{p}$ value should be less than to 0.05 to reject the null hypothesis (Hair, Hult, Ringle, \& e, 2014). In above table 10 the p value 
is less than 0.05 as independent variable entrepreneurship education impact dependent variable that is entrepreneurial behavior because $\mathrm{p}$ value is less than 0.05 which is 0.002 , also the mediating impact of entrepreneurial intention have the significance impact as the value of $p$ is less than 0.05 so the null hypothesis is rejected.

\section{CONCLUSION}

This research is done to find out the impact of entrepreneurship education on entrepreneurial behavior of university student and the mediating effect of entrepreneurial intention. Entrepreneurship education have the significant impact on entrepreneurial behavior and entrepreneurial intention on the other hand entrepreneurial intention have also the significant impact on entrepreneurial behavior of university student. Entrepreneurship education is beneficial for increasing the student's dedication towards entrepreneurship also if they have the positive intentions about entrepreneurship education and to become entrepreneur in future that make their positive behavior towards entrepreneurship making change and innovation in the business industry.

\section{FUTURE RESEARCH RECOMMENDATIONS}

The future dimension and recommendation of this research is to increase the more sample size for getting more accurate results. The new researches are allowed to increase more independent and dependent variable even they can also implement the moderation to check their direct or indirect relationship with their IV and DV. Furthermore, entrepreneurship education has very beneficial for university students also it increase the entrepreneurs in the country so it can help in the growth of economy. 


\section{REFERENCES}

Adenipekun, M., Ibiyemi, A., Adnan, Y. M., \& Daud, M. N. (2015). Comparative analysis of sustainable facilities planning and users' satisfaction in Nigerian universities-a standardized residuals approach. International Journal of Higher Education and Sustainability, 1(1), 40-65.

Ajzen, I. (1991). The theory of planned behavior. Organizational behavior and human decision processes, 50(2), 179-211.

Ajzen, I. (2001). Nature and operation of attitudes. Annual review of psychology, 52(1), 27-58.

Ajzen, I. (2002). Perceived behavioral control, self efficacy and the theory of planned behavior. Journal of applied social psychology, 32(4), 1-20.

Autio, E., Keeley, R. H., Klofsten, M., \& Ulfstedt, T. (1997). Entrepreneurial intent among students: testing an intent model in Asia, Scandinavia and USA.

Buba, M. P., Ayuba, A., \& Aminu, R. (2015). European journal of business and management, 222-283.

Davidsson, P. (1995). Determinants of entrepreneurial intentions. In RENT XI Workshop.

Debarliev, S., Janeshka-lliev, A., Bozhinovska, T., \& Ilieva, V. (2015). ANTECEDENTS of entrepreneurial intention evidence from republic of Macedonia. Business and Economics Horizon, 11(3), 143-161.

Detienne, D. R., \& Chandler, G. N. (2004). Opportunity identification and its role on the entrepreneurial classroom. management learning and education, 242-257.

Douglas, E. J., \& Shepherd, S. (2002). Self-employment as a career choice entrepreneurial intention and utility maximization. International Journal of Business, 26(3), 81-90.

Drennan, J. J., \& Renfrow, P. (2005). Impact of childhood experience on the development of entrepreneurial intentions. International journal of entrepreneurship and innovation, 6 , 231-238.

Dyer, G. W. (1994). Entrepreneurial careers towards a theory. entrepreneurship theories and practice, 19(2), 7-21. 
Farrukh, M., Chong, W. Y., Mansori, S., \& Ravan, R. S. (2017). Entrapreneurial behavior the role of organization commitment. World Journal of Entrepreneurship Management and Sustainable Development, 13(3), 243-256.

Farrukh, M., Wei, Y. C., \& Abdulla, A. (2016). organizational commitment. cogent business and management, 3(1), 1-10.

Farrukh, M., Wei, Y. C., \& Abdullah, A. N. (2016). ORGANIZATIONAL COMMITMENT. Cogent Business Management, 3(1), 1-10.

Fritsch, M. (2011). Start ups in innovative industries causes and effects . international journal of entrepreneurship education, 365-381.

Gibb, A. (2002). In pursuit on a new enterprise and entrepreneurship paradigm. international journal and management, 4(3), 233-269.

Gorman, G., Hanlon, D., \& King, W. (1997). RESEARCH PERSPECTIVE ON ENTREPRENEURSHIP EDUCATION. International small busines journal, 15(3), 5677.

Haris, N. A., \& Rahman, F. A. (2017). A study on application of fuzzy methods in entrepreneurship domain. International Journal of Advanced and Applied Sciences, 4(12), 206-211.

Izedonmi, P. F., \& Okafor, C. (2010). The effect of entrepreneurship education on students entrepreneurial intention. Global journal of management and business research, 1, 4960.

Izquierdo, E., \& Buelens, M. (2008). COMPETING MODEL OF ENTREPRENEURIAL INTENTION. International journal of entrepreneurship education and innovation, 1720.

Kakkonen. (2010). International business students attitude of entrepreneurship. Business related scientific research journal, 1(1), 1-16.

Katz, J. a. (2003). The chronology and intellectual trajectory of American entrepreneurship education. Journal of busines venturing, 18(2), 283-291.

Krueger Jr, N. F., Reilly, M. D., \& Carsrud, A. L. (2000). Competing models of entrepreneurial intention. Journal of business venturing, 15, 411-432. 
Krueger, N., \& Brazeal, D. (1994). entrepreneurship theory and practice, 18(3), 91-104.

Krueger, N., Reilly, M., \& Carsrud, A. (2000). Competing model of entrepreneurial intention. Journal of business venturing, 15(6), 411-432.

Lee, S. H., \& Wong, P. K. (2004). An exploratory study of entrepreneurial intentions . International journal of entrepreneurship education, 56-60.

Linan, F. (2004). Intention based model of entrepreneurship education. Journal of small business management, 3(1), 11-35.

Linan, F., \& Chang, W. Y. (2006). Testing the entrepreneurial intention model on two country sample. small business journal, 8-15.

Linan, F., \& Chen, Y. W. (n.d.). Testing the entrepreneurial intention model on a two country sample .

Linan, F., Rodriguez-Cohard, J. C., \& Rueda-Cantuche, J. M. (2010). Factors effecting entrepreneurial intention levels; a role for education. International entrepreneurship and management journal, 7(2), 195-218.

Mcstay, D. (2008). An investigation of undergraduate student self employment intention and the impact of entrepreneurship education. journal of business education.

Noel, T. (1998). Effect of entrepreneurial education on intent to open a business. Journal of entrepreneurship education, 5(1), 3-13.

Peterman, N. E., \& Kennedy, J. (2003). Perception of entrepreneurship education that influence students. entrepreneurship practice, 129-144.

Pittaway, L., \& Cope, J. (2007). Entrepreneurship education a systemetic review of the evidence. International small business journal, 25(5), 479-510.

Prakash, D., Jain, S., \& Chauhan, K. (2015). Entrepreneurial intensity in relationship with entrepreneurship development. International Journal of Management Education, 13(1), 95-105.

Robinson, P., \& M, H. (2004). Entrepreneurship education in America's major universities. Entrepreneurship theory and practice spring, 41-52. 
Soloman, G. T., \& Fernald, L. W. (2005). Trends in small business and entrepreneurship education. International journal of entrepreneurship education, 15(3), 25-40.

Solomon, G. T., Duffy, S., \& Tarabishy, A. (2002). The state of entrepreneurship education in the united states, a nationwide survey and analysis. International journal of entrepreneurship education, 15(3), 65-86.

Temoor, Sara, \& Farukh. (2018). entrepreneurial intention of Pakistani students. journal of management research.

Thandi, H., \& Sharma, R. (2003). MBA students and entrepreneurship an Australian study of entrepreneurial intention an actualization. JIRSEA, 2(1), 12-23.

Uwameiye, R., \& Uwameiye, B. E. (2006). Attitude of Nigerian university students towards entrepreneurship education. European journal of scientific research, 15(2), 201-206.

Vesalainan, J., \& Pihkala, T. (1999). Motivation structure and entrepreneurial intention . Frontiers of entrepreneurship research, 73-87.

Weaver, M., Dickson, P., \& Soloman, G. (2006). ENTERPRENEURSHIP AND EDUCATION.

Zeithaml, C. P., \& Rice, G. H. (2016). Entrepreneurship business education in American universities. Journal of small business management, 25(1), 44-50.

Zhao, H., Hill, G., \& Seiberts, S. (2005). The mediating role of self-efficacy in the development of entrepreneurial intention. Journal of applied psychology, 90(6), 1265-1272. 